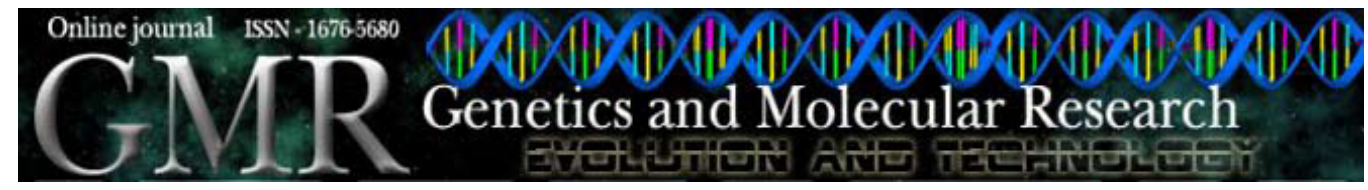

\title{
Recombinogenic effects of the aqueous extract of pulp from pequi fruit (Caryocar brasiliense) on somatic cells of Drosophila melanogaster
}

\author{
A.J.S. Castro ${ }^{1}$, C.K. Grisolia ${ }^{2}$, B.C. de Araújo ${ }^{1}$, C.D. Dias' ${ }^{1}$, E.S. Dutra ${ }^{1}$ \\ and J.C. Nepomuceno ${ }^{1,3}$ \\ ${ }^{1}$ Instituto de Genética e Bioquímica, Universidade Federal de Uberlândia, \\ Uberlândia, MG, Brasil \\ ${ }^{2}$ Departamento de Genética e Morfologia, Instituto de Ciências Biológicas, \\ Universidade de Brasília, Brasília, DF, Brasil \\ ${ }^{3}$ Laboratório de Citogénetica e Mutagênese, \\ Centro Universitário de Patos de Minas, Patos de Minas, MG, Brasil \\ Corresponding author: J.C. Nepomuceno \\ E-mail: nepomuceno@ufu.br
}

Genet. Mol. Res. 7 (4): 1375-1383 (2008)

Received September 12, 2008

Accepted October 13, 2008

Published December 9, 2008

\begin{abstract}
Caryocar brasiliense Camb. is a tree popularly known in Central Brazil as pequi. Its fruit contains carotenes, retinols, vitamin $\mathrm{C}$, and polyphenols. These compounds possess antioxidant properties preventing excessive free radical formation and modulating the genotoxicity of physical and chemical agents in the body. However, at high concentrations these compounds can have recombinogenic and mutagenic effects, because they can act as prooxidants. We examined the genotoxic effects of aqueous extracts of pequi pulp on wing spots of Drosophila melanogaster using the somatic mutation and recombination test (SMART). SMART was applied to a standard cross and to a high bioactivation cross. Two
\end{abstract}


types of descendants were obtained from these crosses: markedheterozygous $\left(m w h+/+f l r^{3}\right)$ and balancer-heterozygous $(m w h+1+$ TM3, Bds). Seventy-two-hour larvae from both crosses were treated with pequi pulp extract at 1,5 and $10 \%$. The extract increased significantly the frequency of mutant spots when compared with the negative control. Recombinogenic effects were also observed in the $m w h / T M 3$ descendants.

Key words: Pequi; Drosophila melanogaster; SMART; Genotoxicity; Doxorubicin; Caryocar brasiliense

\section{INTRODUCTION}

The therapeutic properties of plants are provided by the compounds originating from their secondary metabolism. Among them, terpenoids, phenols, alkaloids, and carotenoids are the most effective. In addition to their antioxidant properties, they can act as modulators of oxidative lesions in DNA (Romero-Jiménez et al., 2005).

Caryocar brasiliense Camb., popularly known as "pequi", is a typical tree of the Brazilian savannah. According to Marques et al. (2002), pequi fruit is commonly used as a regional dish in central Brazil as well as for folk medicine to treat bronchial-respiratory diseases.

Azevedo-Meleiro and Rodriguez-Amaya (2004) discovered that the content of the pulp of pequi is rich in nutritional compounds such as fatty acids, carbohydrates, proteins, carotenes, vitamin E, and retinol. According to Almeida (1998), the pulp of this fruit also has high levels of pectin and tannins in addition to polyunsaturated oils.

The somatic mutation and recombination test (SMART), developed with Drosophila melanogaster, is an assay that permits the detection of a range of genetic alterations, such as DNA point mutation, nucleotide deletion in DNA and mitotic DNA recombination (Graf et al., 1984). Flies with gene markers, such as multiple wing hairs ( $m w h)$ and flare $^{3}\left(\right.$ flr $\left.^{3}\right)$, are used to detect the loss of heterozygosis in these genes. During the embryonic development of D. melanogaster, the cells of the imaginal disk proliferate mitotically to form the body of the adult fly. Genetic alterations in some of these cells of the imaginal disk result in the formation of descent cells with alterations, forming clones of mutant cells. Such alterations are easily detected by phenotypic modifications in the hairs of the wings of the adult fly (Guzmán-Rincón and Graf, 1995).

Doxorubicin (DXR) is a chemotherapeutic agent used in the treatment of several human neoplasms. DXR is a DNA-intercalating compound, which induces a wide variety of free radicals and also inhibits topoisomerase II. For these reasons, it is an effective clastogen on somatic and germinative as well as recombinogenic cells (da Rocha et al., 2001; Hardman et al., 2002). In D. melanogaster SMART, DXR induces recombinations and is therefore used as a positive control (Costa and Nepomuceno, 2006; Fragiorge et al., 2007).

Considering that the fruit of the pequi tree is rich in carotenes, vitamins $\mathrm{A}$ and $\mathrm{C}$ and many other compounds with antioxidant effects, investigations as to the mode of its possible interactions with genetic material have stirred interest. The aim of the present study was to determine the genotoxic potential of the aqueous extract of the pulp from pequi fruit using SMART on the wings of $D$. melanogaster. 


\section{MATERIAL AND METHODS}

\section{Chemical agent}

Doxorubicin (CAS 23214-92-8), known commercially as Doxolem ${ }^{\circledR}$, is manufactured by Eurofarma Laboratórios Ltda., São Paulo, SP, Brazil. Each vial contains $10 \mathrm{mg}$ lyophilized DXR. It possesses a molecular mass of $580 \mathrm{kDa}$ and a molecular structure of $\mathrm{C}_{27} \mathrm{H}_{29} \mathrm{NO}_{11} \cdot \mathrm{HCl}$.

\section{Preparation of the aqueous extract of pequi (Caryocar brasiliense) pulp}

The fresh fruit of the pequi was purchased at the local market in the city of Brasília, and its pulp was immediately extracted in the Laboratory of Organic Chemistry of the University of Brasília. The pulp was placed in a Soxhlet extractor in the proportion of $100 \mathrm{~g}$ to $1 \mathrm{~L}$ distilled water. The extraction process was protected from the air in an atmosphere of argon. The extract was maintained in the Soxhlet extractor for $10 \mathrm{~h}$, then concentrated in a rotary evaporator for $24 \mathrm{~h}$ and frozen at $-80^{\circ} \mathrm{C}$.

\section{Stock of Drosophila and crosses}

Stocks of three mutant strains of $D$. melanogaster were selected for use in this study: multiple wing hairs $(\mathrm{mwh} / \mathrm{mwh})$; flare $^{3}\left(\mathrm{fl}^{3} / T M 3, B d^{s}\right)$, and ORR (ORR/ORR; $\left.f r^{3} / T M 3, B d^{s}\right)$ (Graf et al., 1984). The strain ORR (Oregon R) was used due to its elevated capacity for expression of cytochrome P450 (Frölich and Würgler, 1989).

With these strains, two crosses were made: 1) standard (ST) cross: virgin females of

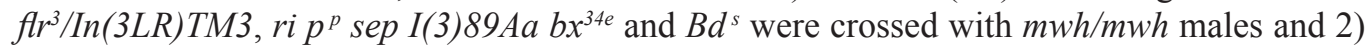
high bioactivation (HB) cross: virgin females ORR/ORR; $\mathrm{fr}^{3} / \operatorname{In}(3 L R) T M 3$, ri $p^{p}$ sep I(3)89Aa $b x^{34 e}$ and $B d^{s}$ were crossed with $m w h / m w h$ males (Graf and van Schaik, 1992).

\section{Collection of larvae and treatment}

From both crosses, eggs were collected during a period of $8 \mathrm{~h}$ in culture flasks with an agar-agar $(4 \%, \mathrm{w} / \mathrm{v})$ base covered with a thick layer of live biological yeast supplemented with sucrose. The 72-h-old larvae, in the third stage of embryonic development, were washed in running water and fed for a period of $48 \mathrm{~h}$ on $1.5 \mathrm{~g}$ instant mashed potatoes (Yoki Alimentos S.A., Brazil) and $5 \mathrm{~mL}$ of varying concentrations of aqueous extracts of pequi pulp (AEP) at 1, 5, and 10\%. Negative control (sterile distilled water) and positive DXR $(0.125 \mathrm{mg} / \mathrm{mL})$ were included in the treatments. All experiments were kept at a temperature of $25^{\circ} \mathrm{C}$ and $65 \%$ relative humidity.

Each cross produced two types of progeny: marked-trans-heterozygous flies (MH) $\left(m w h f r^{+} / m w h^{+} f l r^{3}\right)$ and balancer-heterozygous flies (BH) $\left(m w h f l r^{+} / m w h^{+} T M 3, B d^{s}\right)$. The adult flies were fixed in $70 \%$ ethanol, and the wings were mounted in Faure solution $(30 \mathrm{~g}$ gum Arabic, $20 \mathrm{~mL}$ glycerol, $50 \mathrm{~g}$ chloral hydrate and $50 \mathrm{~mL}$ water) and analyzed under a microscope (400X). The positions of the spots were noted according to wing sections (Graf et al., 1984). 


\section{Statistical analysis}

The frequency of each type of mutant clone among the treated flies was compared with the frequency found in the negative control group using the conditional binomial test of Kastenbaum and Bowman (1970). The possible results for this test are: positive, weakpositive, negative or inconclusive (Frei and Würgler, 1988).

\section{RESULTS}

Table 1 shows the frequencies of mutant spots among the MH descendants $\left(m w h / f r^{3}\right)$ and $\mathrm{BH}(m w h / T M 3)$ of the ST cross, treated with AEP at concentrations of 1,5 , and $10 \%$. DXR $(0.125$ $\mathrm{mg} / \mathrm{mL})$ significantly increased the frequency of all classes of spots $(\mathrm{P} \leq 0.05)$. The increase in twin spots indicates that DXR is recombinogenic. A statistically significant increase in the total number of spots was observed only among the flies treated with a $10 \%$ concentration, compared with the spot frequencies observed in the negative control. The analysis of flies with genotype $m w h / T M 3$ was carried out for the purpose of calculating the portion of recombinogenic and mutagenic events. It was found that in flies with genotype $m w h / T M 3$ the recombinational events were eliminated by the presence of multiple inversions in the balancer chromosome TM3.

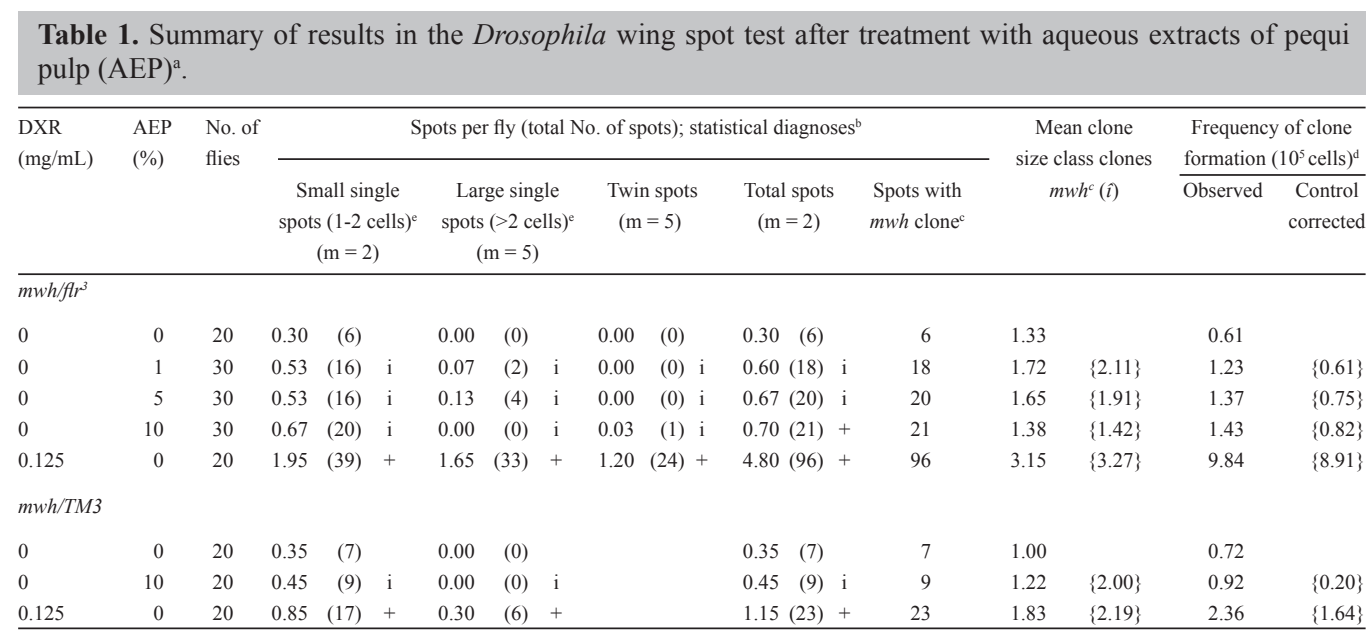

${ }^{a}$ Larvae from standard cross. Marker-trans-heterozygous flies $\left(m w h / f l r^{3}\right)$ and balancer-heterozygous flies $(m w h /$ TM3) were evaluated.

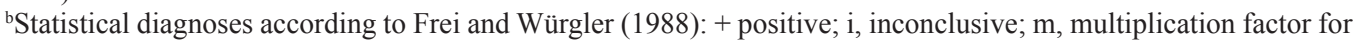
the assessment of significantly negative results. Significance levels $\alpha=\beta=0.05$.

${ }^{c}$ Considering $m w h$ clones from $m w h$ single and twin spots.

${ }^{\mathrm{d}}$ Frequency of clone formation: clones/fly/48,800 cells (without size correction).

'Including rare $f l r^{3}$ single spots. DXR = doxorubicin.

Analysis of the $m w h / T M 3$ flies, resulting from the ST cross treated with AEP at 10\%, revealed no induction of mutagenic activity in all categories of spots. However, the percentage of mutant spots resulting from mutations was $64.3 \%$ and from recombination, $35.7 \%$. In view of the negative results observed in the trans-heterozygous descendants of the ST cross, treated 
with AEP with 1 and 5\%, the descendants of $m w h / T M 3$ were not analyzed.

Table 2 shows the frequency of mutant spots observed in the $m w h / f r r^{3}$ and $m w h / T M 3$ descendants. This table also presents the data of the high metabolic bioactivation (HB) cross treated at concentrations of 1,5 , and $10 \%$. A statistically significant increase was observed in spot frequency at all tested concentrations of the $m w h / f r^{3}$ descendants of the $\mathrm{HB}$ cross. In the small simple spot category, a significant increase $(\mathrm{P} \leq 0.05)$ was also demonstrated at concentrations of 1 and 5\% AEP. The DXR showed genotoxic activity by increasing the frequencies of all types of spots $(\mathrm{P} \leq 0.05)$, for individuals of the HB cross.

\begin{tabular}{|c|c|c|c|c|c|c|c|c|c|c|c|c|c|}
\hline \multirow{2}{*}{$\begin{array}{l}\text { DXR } \\
(\mathrm{mg} / \mathrm{mL})\end{array}$} & \multirow{2}{*}{$\begin{array}{l}\text { AEP } \\
(\%)\end{array}$} & \multirow{2}{*}{$\begin{array}{l}\mathrm{N}^{\circ} \text { of } \\
\text { flies }\end{array}$} & \multicolumn{7}{|c|}{ Spots per fly (total No. of spots); statistical diagnoses ${ }^{b}$} & \multicolumn{2}{|c|}{$\begin{array}{l}\text { Mean clone } \\
\text { size class }\end{array}$} & \multicolumn{2}{|c|}{$\begin{array}{l}\text { Frequency of clone } \\
\text { formation } / 10^{5} \text { cells }\end{array}$} \\
\hline & & & \multicolumn{2}{|c|}{$\begin{array}{c}\text { Small single } \\
\text { spots }(1-2 \text { cells })^{\mathrm{e}} \\
\quad(\mathrm{m}=2)\end{array}$} & \multicolumn{2}{|c|}{$\begin{array}{c}\text { Large single } \\
\text { spots }(>2 \text { cells })^{\mathrm{e}} \\
\quad(\mathrm{m}=5)\end{array}$} & $\begin{array}{l}\text { Twin spots } \\
\quad(\mathrm{m}=5)\end{array}$ & $\begin{array}{l}\text { Total spots } \\
\quad(\mathrm{m}=2)\end{array}$ & $\begin{array}{c}\text { Spots with } \\
m w h \\
\text { clone }^{\mathrm{c}}\end{array}$ & & & Observed & $\begin{array}{c}\text { Control } \\
\text { corrected }\end{array}$ \\
\hline \multicolumn{14}{|l|}{$m w h / f r^{3}$} \\
\hline 0 & 0 & 20 & 1.15 & & 0.10 & $(2)$ & $0.05 \quad(1)$ & $1.30 \quad(26)$ & 26 & 1.54 & & 2.66 & \\
\hline 0 & 1 & 29 & $1.90 \quad(55)$ & + & 0.14 & (4) $\mathrm{i}$ & $0.00 \quad(0) \quad \mathrm{i}$ & $2.03 \quad(59)$ & 58 & 1.45 & $\{1.28\}$ & 4.10 & $\{1.43\}$ \\
\hline 0 & 5 & 29 & $1.76 \quad(51)$ & $\mathrm{i}$ & 0.24 & (7) $\mathrm{i}$ & $0.00 \quad(0) \quad \mathrm{i}$ & $2.00 \quad(58)$ & 56 & 1.63 & $\{1.80\}$ & 3.96 & $\{1.29\}$ \\
\hline 0 & 10 & 28 & $2.11 \quad(59)$ & + & 0.07 & (2) $\mathrm{i}$ & $0.00 \quad(0) \quad \mathrm{i}$ & $2.18 \quad(61)$ & 61 & 1.54 & $\{1.54\}$ & 4.46 & $\{1.80\}$ \\
\hline 0.125 & 0 & 20 & 3.35 (67) & + & 2.50 & $(50)+$ & $1.50(30)+$ & 7.35 (147) & 143 & 3.17 & $\{3.54\}$ & 14.65 & $\{10.92\}$ \\
\hline \multicolumn{14}{|l|}{$m w h / T M 3$} \\
\hline 0 & 0 & 20 & $0.70 \quad$ (14) & & 0.00 & $(0)$ & & 0.70 & 14 & 1.36 & & 1.51 & \\
\hline 0 & 1 & 20 & $0.45 \quad$ (9) & - & 0.00 & (0) $\mathrm{i}$ & & $0.45 \quad(9)$ & 9 & 1.00 & $\{1.92\}$ & 0.92 & $-\{0.59\}$ \\
\hline 0 & 5 & 20 & $0.65 \quad$ (13) & - & 0.00 & (0) $\mathrm{i}$ & & $0.65 \quad(13)$ & 13 & 1.38 & $\{1.15\}$ & 1.33 & $-\{0.18\}$ \\
\hline 0 & 10 & 20 & $0.55 \quad$ (11) & - & 0.00 & (0) $\mathrm{i}$ & & 0.55 & 11 & 1.27 & $\{1.61\}$ & 1.13 & $-\{0.38\}$ \\
\hline 0.125 & 0 & 20 & $1.05 \quad(21)$ & $\mathrm{i}$ & 0.05 & (1) $\mathrm{i}$ & & $1.10 \quad(22)$ & 22 & 1.32 & $\{1.24\}$ & 2.25 & $\{0.74\}$ \\
\hline
\end{tabular}

aLarvae from high bioactivation cross. Marker-trans-heterozygous flies $\left(m w h / f r^{3}\right)$ and balancer-heterozygous flies $(m w h / T M 3)$ were evaluated.

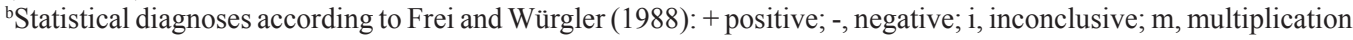
factor for the assessment of significantly negative results. Significance levels $\alpha=\beta=0.05$.

${ }^{\mathrm{c} C o n s i d e r i n g} m w h$ clones from $m w h$ single and twin spots.

${ }^{\mathrm{d}}$ Frequency of clone formation: clones/fly/48,800 cells (without size correction).

'Including rare $f r^{3}$ single spots. DXR = doxorubicin.

The results of the experiments using flies with genotype $m w h / T M 3$ of the HB cross showed no statistically significant increase $(\mathrm{P}>0.05)$ at all tested concentrations and in all categories of mutant spots. Therefore, at the three concentrations tested, no increase in mutagenicity was observed. On the other hand, the portions of recombinogenic events, for the same cross, were of $77.5,66.5$, and $74.7 \%$ for the concentrations of 1,5 , and $10 \%$, respectively.

\section{DISCUSSION}

The pequi fruit is rich in substances with antioxidant properties, such as carotenes, vitamin A (20,000 U/100 g pulp) and vitamin C (12 mg/100 g pulp) (Azevedo-Meleiro and Rodrigues-Amaya, 2004). Besides the polyphenol content in the oily fraction, these compounds 
are considered to be natural inhibitors of oxidative agents and important in the prevention of cancer and other degenerative diseases (Odin, 1997). Many studies report on the modulatory effects of such antioxidant compounds in different test-systems such as Salmonella typhimurium (Tavan et al., 1997), human lymphocytes in vitro (Antunes and Takahashi, 1999) and $D$. melanogaster (Costa and Nepomuceno, 2006).

The use of $D$. melanogaster in the evaluation of genotoxicity has been well established as a test-system. Due to a genome similarity compared to mammals and easy maintenance in the laboratory, these flies represent an appropriate organism to run in vivo short-term tests (Graf et al., 1996; Vogel et al., 1999). SMART is a simple and fast short-term assay compared with other in vivo tests. It is effortless to conduct and effective in the detection of a wide range of aspects of genetic alterations (Graf et al., 1984, 1989). It is thus possible, using strains of $D$. melanogaster of high metabolic bioactivation (HB), to detect genotoxins such as promutagens, which require metabolic activation by cytochrome enzymes, and act directly as well as indirectly on DNA. Through the use of these test-systems, it is possible to evaluate the genotoxic activity of a single compound as well as complex mixtures (Graf and Würgler, 1996). Analysis of the MH descendants $\left(m w h / f l r^{3}\right)$ and of the BH descendants ( $\left.m w h / T M 3\right)$ has demonstrated that it is possible to quantify the recombinogenic events in the total of mutant spots detected (Spanó et al., 2001). Thus, due to its capabilities, SMART was chosen to evaluate the genotoxic effects of the aqueous pequi extract.

Using the wings heterozygous for multiple inversions on the TM3 balancer chromosome, it is possible to separate mutational events from recombinational events because the recombinational events are eliminated in flies with this genotype. Comparison of the clone induction frequencies obtained for DXR treatment alone in both genotypes indicates that in ST flies $24 \%$ of mutant clones produced by DXR were due to mutation and $76 \%$ to recombination. Also, this same analysis showed that in HB flies $15 \%$ of spots induced by DXR were due to mutation and $85 \%$ to recombination. The strong recombinogenic activity of DXR in the somatic cells of D. melanogaster was previously reported by Costa and Nepomuceno (2006) and Fragiorge et al. (2007).

The cytochrome P450 enzymes belong to the phase I metabolism fraction of xenobiotics. Phytochemicals can also be activated by this fraction from promutagens to mutagens (Sun et al., 2000). Enzymes of D. melanogaster (strain of bioactivation - HB) may have acted on AEP, promoting its rapid metabolism and generating by-products with genotoxic properties. Frölich and Würgler (1989) demonstrated that promutagens can increase the frequency of mutant spots in the descendents of HB cross after metabolism by cytochrome P450 enzymes. AEP effectively promoted mutant spot formation in the HB cross probably because it requires bioactivation to become genotoxic. AEP at a concentration of $10 \%$ increased the frequency of mutant spots in the ST flies. It was deduced that possibly, at this concentration (10\%), bio-transformation of some compound present in the extract may have occurred, since the descendants of the ST cross were not totally free of cytochrome P450 enzymes and possessed their own metabolic capabilities.

According to Graf et al. (1984), the emerging $m w h / T M 3$ flies show mutant spots only due to punctual mutations, deletion or lack of separation. In the present analysis of the $m w h / T M 3$ descendants, of the HB cross, there was no statistically significant increase in mutant spots induced by the AEP, suggesting that the mutant spots observed in the $\mathrm{MH}$ 
descendants were due to the occurrence of recombination $(77.5,66.5$, and $74.7 \%$ for the concentrations of 1,5 , and $10 \%$, respectively). In flies from the ST cross, for the concentration of $10 \%$, the mutation rate $(64.3 \%)$ was higher than the recombination rate $(35.7 \%)$, although no significant difference in the analysis of the $m w h / T M 3$ descendants was found. These results indicate that AEP, after having been metabolized by the cytochrome P450, provoked a recombinogenic effect.

The genotoxicity attributed to AEP (Tables 1 and 2) could be due to the high concentrations of the extract $(1,5$, and $10 \%)$ on the exposed larvae. The chemical composition of the extracts was not determined. However, the extraction processes produced pure and concentrated extract, preserving the chemical and biological properties. Hatching rates and post-metamorphosis development, as compared with the control, were not found to be affected. The concentrated extracts may have elevated contents of carotenoids, vitamin A, vitamin C, and polyphenols, making it possible for them to act as pro-oxidants on the DNA of exposed larvae.

The presence of many antioxidant compounds in the pequi fruit, tested using highly concentrated extracts, could be the cause of its pro-oxidative effect on DNA. Vitamin A (retinol), at elevated doses, has produced genotoxicity when subjected to the SMART and comet assays. Ascorbic acid, known as an antioxidant compound, has shown genotoxicity when evaluated at high doses in different test-systems (Tripathy et al., 1990; Klamt et al., 2003). Antunes and Takahashi (1999) discovered that vitamin C produces antimutagenic activity in human peripheral blood lymphocytes in vitro at certain concentrations. When applied at higher concentrations, it did not display protective effects against mutations; on the contrary, it induced cytotoxicity in lymphocytes.

Young and Lowe (2001) reported on the pro-oxidant effect of $\beta$-carotenes using the comet assay in HT29 cells when tested at high doses. They demonstrated that with concentrations of $\beta$-carotene higher than $4 \mathrm{nM}$, the protective effect was lost and that concentrations above $10 \mathrm{nM}$ were associated with DNA damage. It was concluded that exposure to high concentrations of $\beta$-carotene can affect the cell membrane properties increasing their permeability.

Khouri et al. (2007), who found a lack of genotoxic activity, on the contrary, reported protective effects against the clastogenic action of the bleomycin, used as an inductor of free radicals in mice treated orally with $30 \mu \mathrm{L}$ AEP for 10 days, applying the micronucleus test. This may have been due to the fact that extracts at lower concentrations than those used with the Drosophila larvae were given orally to mice. Thus, at lower concentrations AEP may have produced only anticlastogenic and antioxidant effects. We also suggest that the contradictory responses for AEP in previous studies may partially be due to the extract being a better recombinogenic than mutagenic. SMART is capable of detecting point mutation, deletion and gene recombinations while the micronucleus test detects only clastogenic and aneugenic effects (von Ledebur and Schmid, 1973; Yamamoto and Kikushi, 1980; Graf et al., 1984). For this reason, SMART is capable of detecting a larger spectrum of genotoxic events as compared with the micronucleus test. On the other hand, the increased frequency of mutant spots observed in the present study, could be attributed to an unidentified compound in the AEP with genotoxic potential, since this extract is a complex mixture not yet completely evaluated.

In conclusion, under the present experimental conditions, our data show that AEP is 
genotoxic to Drosophila melanogaster and that mitotic recombination proved to be the major event responsible for this genotoxicity in the SMART assay. This effect was increased after metabolism by the cytochrome P450 enzymes. Given the importance of this fruit as a regional food and folk medicine and due to its wide distribution in the Brazilian savannah, future studies need to be performed to gain a better understanding of its genotoxicity.

\section{REFERENCES}

Almeida SP (1998). Frutas Nativas do Cerrado: Caracterização Físico-Química e Fonte de Nutrientes. In: Cerrado: Ambiente e Flora (Sano SM and Almeida SP, eds.). EBRAPA-CPAC, Planaltina, 247-287.

Antunes LM and Takahashi CS (1999). Protection and induction of chromosomal damage by vitamin C in human lymphocyte cultures. Teratog. Carcinog. Mutagen. 19: 53-59.

Azevedo-Meleiro CH and Rodriguez-Amaya DB (2004). Confirmation of the identity of the carotenoids of tropical fruits by HPLC-DAD and HPLC-MS. J. Food. Comp. Anal. 15: 385-396.

Costa WF and Nepomuceno JC (2006). Protective effects of a mixture of antioxidant vitamins and minerals on the genotoxicity of doxorubicin in somatic cells of Drosophila melanogaster. Environ. Mol. Mutagen. 47: 18-24.

da Rocha AB, Lopes RM and Schwartsmann G (2001). Natural products in anticancer therapy. Curr. Opin. Pharmacol. 1: 364-369.

Fragiorge EJ, Spanó MA and Antunes LMG (2007). Modulatory effects of the antioxidant ascorbic acid on the direct genotoxicity of doxorubicin in somatic cells of Drosophila melanogaster. Genet. Mol. Biol. 30: 449-455.

Frei H and Würgler FE (1988). Statistical methods to decide whether mutagenicity test data from Drosophila assays indicate a positive, negative, or inconclusive result. Mutat. Res. 203: 297-308.

Frölich A and Würgler FE (1989). New tester strains with improved bioactivation capacity for the Drosophila wing-spot test. Mutat. Res. 216: 179-187.

Graf U and van Schaik N (1992). Improved high bioactivation cross for the wing somatic mutation and recombination test in Drosophila melanogaster. Mutat. Res. 271: 59-67.

Graf U and Wurgler FE (1996). The somatic white-ivory eye spot test does not detect the same spectrum of genotoxic events as the wing somatic mutation and recombination test in Drosophila melanogaster. Environ. Mol. Mutagen. 27: $219-226$

Graf U, Würgler FE, Katz AJ, Frei H, et al. (1984). Somatic mutation and recombination test in Drosophila melanogaster. Environ. Mutagen. 6: 153-188.

Graf U, Frei H, Kagi A, Katz AJ, et al. (1989). Thirty compounds tested in the Drosophila wing spot test. Mutat. Res. 222: 359-373.

Graf U, Spanó MA, Gusmán-Rincón J, Abraham Sk, et al. (1996). The wing somatic mutation and recombination test (SMART) in Drosophila melanogaster: An efficient tool for the detection of genotoxic activity of pure compounds or complex mixtures as well as for studies of antigenotoxicity. Afr. Newslett Occup. Heal. Safety 6: 9-13.

Guzmán-Rincón J and Graf U (1995). Drosophila melanogaster Somatic and Recombination Test as a Biomonitor. In: Biomonitors and Biomarkers as Indicators of Environmental Change (Butterworth FM, Corkun LD and GuzmánRincón J, eds.). Plenum Press, New York, 169-181.

Hardman JG, Limbrid LE and Gilman AG (2002). The Pharmacological Basis of Therapeutic. McGraw Hill, New York.

Kastenbaum MA and Bowman KO (1970). Tables for determining the statistical significance of mutation frequencies. Mutat. Res. 9: 527-549.

Khouri J, Resck IS, Poças-Fonseca M, Sousa TMM, et al. (2007). Anticlastogenic potential and antioxidant effects of an aqueous extract of pulp from the pequi tree (Caryocar brasiliense Camb). Genet. Mol. Biol. 30: 442-448.

Klamt F, Dal-Pizzol F, Roehrs R, de Oliveira RB, et al. (2003). Genotoxicity, recombinogenicity and cellular preneoplasic transformation induced by vitamin A supplementation. Mutat. Res. 539: 117-125.

Marques MCS, Cardoso MG, Souza PE, Gavilanes ML, et al. (2002). Efeito fungitóxico dos extratos de Caryocar brasiliense Camb. sobre os fungos Botrytis cineria, Colletotrichum truncatum e Fusarium oxysporum. Ciênc. Agrotec. (Edição Especial): 1410-1419.

Odin AP (1997). Vitamins as antimutagens: advantages and some possible mechanisms of antimutagenic action. Mutat. Res. 386: 39-67.

Romero-Jiménez M, Campos-Sanchez J, Analla M, Munoz-Serrano A, et al. (2005). Genotoxicity and anti-genotoxicity of some traditional medicinal herbs. Mutat. Res. 585: 147-155.

Spanó MA, Frei H, Würgler FE and Graf U (2001). Recombinogenic activity of four compounds in the standard and high 
bioactivation crosses of Drosophila melanogaster in the wing spot test. Mutagenesis 16: 385-394.

Sun M, Sakakibara H, Ashida H, Danno G, et al. (2000). Cytochrome P4501A1-inhibitory action of antimutagenic anthraquinones in medicinal plants and the structure-activity relationship. Biosci. Biotechnol. Biochem. 64: 1373-1378.

Tavan E, Maziere S, Narbonne JF and Cassand P (1997). Effects of vitamins A and E on methylazoxymethanol-induced mutagenesis in Salmonella typhimurium strain TA100. Mutat. Res. 377: 231-237.

Tripathy NK, Würgler FE and Frei H (1990). Genetic toxicity of six carcinogens and six non-carcinogens in the Drosophila wing spot test. Mutat. Res. 242: 169-180.

Vogel EW, Graf U, Frei H and Nivard MMJ (1999). The Results of Assay in Drosophila as Indicators of Exposure to Carcinogens. In: The Use of Short and Medium-term Test for Carcinogens and Data on Genetic Effects in Carcinogenic Hazard Evaluation (McGregor DB, Rice JM and Venitt S, eds.). IARC Scientific Publications, Lyon, 427-470.

von Ledebur M and Schmid W (1973). The micronucleus test. Methodological aspects. Mutat. Res. 19: 109-117.

Yamamoto KI and Kikuchi Y (1980). A comparison of diameters of micronuclei induced by clastogens and by spindle poisons. Mutat. Res. 71: 127-131.

Young AJ and Lowe GM (2001). Antioxidant and prooxidant properties of carotenoids. Arch. Biochem. Biophys. 385: 20-27. 